\title{
Nitrogen Dioxide and Ozone Pollution in the Chicago Metropolitan Area
}

\author{
Zixian Wang1, Jennifer L. Anthony¹, Larry E. Erickson', Michael J. Higgins², Gregory L. Newmark ${ }^{3}$ \\ ${ }^{1}$ Tim Taylor Department of Chemical Engineering, Kansas State University, Manhattan, KS, USA \\ ${ }^{2}$ Department of Statistics, Kansas State University, Manhattan, KS, USA \\ ${ }^{3}$ Department of Landscape Architecture/Regional and Community Planning, Kansas State University, Manhattan, KS, USA \\ Email: zixian@ksu.edu, anthonyj@ksu.edu, lerick@ksu.edu, mikehiggins@ksu.edu,gnewmark@ksu.edu
}

How to cite this paper: Wang, Z.X., Anthony, J.L., Erickson, L.E., Higgins, M.J. and Newmark, G.L. (2020) Nitrogen Dioxide and Ozone Pollution in the Chicago Metropolitan Area. Journal of Environmental Protection, 11, 551-569. https://doi.org/10.4236/jep.2020.118033

Received: July 4, 2020

Accepted: July 28, 2020

Published: July 31, 2020

Copyright (c) 2020 by author(s) and Scientific Research Publishing Inc. This work is licensed under the Creative Commons Attribution International License (CC BY 4.0).

http://creativecommons.org/licenses/by/4.0/

\begin{abstract}
Ground-level ozone is a harmful air pollutant associated with several health issues. Ozone concentrations have exceeded the National Ambient Air Quality Standards (NAAQS) in the Chicago metropolitan area on hot summer days for many years because of nitrogen oxide and volatile organic compound emissions. Annual fourth highest 8-hour ozone concentrations have been between 0.070 and $0.084 \mathrm{ppm}$ at several monitoring sites in Cook county, during the 2016-2018 time period. The continuous measurement of nitrogen dioxide $\left(\mathrm{NO}_{2}\right)$ and ozone $\left(\mathrm{O}_{3}\right)$ was conducted in several communities in Chicago in 2017. The air pollution impacts the health of all who live in the area. The data were used to analyze correlations between the $\mathrm{O}_{3}$ distribution and its association with ambient concentrations of $\mathrm{NO}_{2}$ from transportation emissions. Higher concentrations in $\mathrm{NO}_{2}$ and $\mathrm{O}_{3}$ occurred in succession in the daytime. The diurnal variation of $\mathrm{O}_{3}$ concentration was analyzed. The daily cycle of $\mathrm{NO}_{2}$ concentration reaches a maximum in the late morning and has smaller nighttime concentrations. The daily cycle of ozone concentration reaches the maximum in the afternoon and also becomes smaller for nighttime concentrations. In addition, relationships were found between $\mathrm{O}_{3}$ and $\mathrm{NO}_{2}$. Monthly variations of ozone and $\mathrm{NO}_{2}$ are presented. Some options to reduce ozone pollution are presented.
\end{abstract}

\section{Keywords}

Volatile Organic Compounds, Health, Vehicle Emissions, Daily Transient Cycles, Ozone Precursors, Photochemical Reactions

\section{Introduction}

Ozone $\left(\mathrm{O}_{3}\right)$ is a key secondary air pollutant associated with a number of health 
issues including asthma and premature death [1] [2] [3]. Because of its effects on people and the environment, ground-level ozone is a harmful air pollutant and the main ingredient in smog [2]. According to the American Lung Association, more than $40 \%$ of Americans currently live in areas with unhealthy levels of ozone pollution [3]. The importance of climate change for $\mathrm{O}_{3}$ air pollution has been highlighted by past studies estimating health impacts of projected $\mathrm{O}_{3}$ increases over the 21st century [1] [4]. However, the problem of ozone pollution related to $\mathrm{NO}_{2}$ emissions continues to be a serious issue. Jing et al. pointed out that despite strenuous efforts to reduce the emissions of ozone precursors such as nitrogen oxides $\left(\mathrm{NO}_{x}\right)$, concentrations of ground-level ozone $\left(\mathrm{O}_{3}\right)$ still often exceed the National Ambient Air Quality Standard in U.S. cities in summertime, including Chicago [4]. Pollution of ozone is caused by the photochemical reaction of precursor volatile organic compounds (VOCs) and nitrogen oxides $\left(\mathrm{NO}_{x}\right)$, with a major source of nitrogen dioxide $\left(\mathrm{NO}_{2}\right)$ being traffic emissions. In many areas, nitrogen oxides in air have been a pollution problem for more than 20 years [3] [4] [5]. There are three nitrogen oxides-nitrous oxide $\left(\mathrm{N}_{2} \mathrm{O}\right)$, nitric oxide (NO), and nitrogen dioxide-that are found in air as gas [6]. $\mathrm{NO}_{2}$ is the most important of these air pollutants because of concentration and health impacts [6]. The chemical reactions related to ozone formation are presented in Discussion.

To determine the optimal emission control strategy, understanding the complexity of the diurnal ozone process and its relationship to precursors is critical [7]. In recent years, the governments of the world have been more concerned about ozone pollution and its harm to human health. They have tried to make policies and management measures to reduce ozone pollution. We need to continue to advance public policies and cooperative efforts to have better control of ozone pollution. Exposure of vegetation to tropospheric ground level ozone causes an alteration in the allocation of resources, which can affect all aspects of plant growth. Urban heat island phenomenon and the related problems of ozone in Chicago's metropolitan area are also major problems. The thermal processes that are active in a heat island start early morning with the sunrise, continue throughout the day, and often last through the night [8]. Temperature is important because it affects ozone formation and human health.

A county is defined as out of attainment with the National Ambient Air Quality Standard (NAAQS) for ozone if the 3-year average of the annual 4th highest maximum 8-hour average exceeds $70 \mathrm{ppb}$ [9]. Since the Industrial Revolution, Chicago has struggled with air pollution like many other major U.S. cities. Although emissions of ozone-precursors and summertime ozone levels have decreased significantly since the late 1970's, ozone in Chicago has never complied fully with standards set by the EPA to protect public health [3] [10]. Transportation has a negative impact on health because of its negative impact on air quality [11]. The main objective of this work is to analyze the issues of ozone air pollution caused by $\mathrm{NO}_{2}$ emissions from transportation in Chicago. Emissions of volatile organic compounds (VOCs) contribute to ozone formation also [4] [6]. 
In Cook County, Illinois, there were 36 days when the ozone concentration exceeded $70 \mathrm{ppb}$ and was in the orange range of the Air Quality Index from 71 85 ppb during 2015-2017 and 4 days when the ozone concentration was in the red range from $86-105 \mathrm{ppb}$ [3]. Ozone concentrations are influenced by $\mathrm{NO}_{2}$ concentrations because $\mathrm{NO}_{2}$ can produce ozone via chemical reactions as shown in Section 4. More traffic produces more $\mathrm{NO}_{x}$ from vehicle exhaust, which then produces more ozone [11]-[22].

In March and April 2020, there was a reduction in nitrogen oxide emissions because of executive orders issued by the governor in response to the COVID-19 pandemic to stay home and reduce risk of spreading the virus [12]. Comparing the same periods of March and April between 2019 and 2020 in Table 1, the average daily max 8-hr ozone concentration and the average daily $\max 1$-hr $\mathrm{NO}_{2}$ concentration are lower during 2020, including more obvious difference for $\mathrm{NO}_{2}$ values. The data may be found in outdoor air quality data of EPA. Because of COVID-19, many people followed the executive orders and stayed at home and reduced their transportation emissions in March and April 2020. This data shows that concentrations of nitrogen dioxide in ambient air in Chicago can be reduced by reducing vehicle emissions.

\section{Methods, Study Region \& Data Scope}

The study regions include two communities in Chicago, which are Little Village (LV) and South Loop (SL). All collected data were provided by Shared Air/Shared Action (SASA) project [13]. The data may be found at http://fingolfin.kdd.cs.ksu.edu:8080/airquality/download/. SASA is Community Empowerment through Low-Cost Air Pollution Monitoring, an EPA Air Pollution Monitoring for Communities Grant [14]. Low-cost monitors "Aeroqual" for the SASA project (SASA_AQ) were utilized to monitor $\mathrm{NO}_{2}$ and $\mathrm{O}_{3}$ concentration in the communities, and many regulatory monitors from EPA also were used to monitor the neighborhood of the communities [13] [14] [22].

The locations of the EPA nitrogen dioxide and ozone monitoring sites in Cook county for the values in all tables and figures in the study are given below:

1) 170310001-Village Garage, 4500 W. 123rd Street, Alsip

2) $170310032-$ South Water Filtration Plant, 3300 E. Cheltenham Place, Chicago

3) 170310063-Public Garage, 321 S. Franklin, Chicago

Table 1. Comparison of March and April $\mathrm{NO}_{2}$ and $\mathrm{O}_{3}$ values between 2019 and 2020 in Cook County, Illinois.

\begin{tabular}{ccccc}
\hline & \multicolumn{2}{c}{$\begin{array}{c}\text { Average daily max 8-hr } \\
\text { concentration, } \mathrm{ppm}\end{array}$} & \multicolumn{2}{c}{$\begin{array}{c}\text { Average daily max 1-hr } \mathrm{NO}_{2} \\
\text { Concentration, ppm }\end{array}$} \\
\cline { 2 - 4 } & 2019 & 2020 & 2019 & 2020 \\
\hline March & 0.03844 & 0.03122 & 0.037806 & 0.028094 \\
April & 0.04143 & 0.04050 & 0.030590 & 0.028197 \\
\hline
\end{tabular}


4) 170310076-Com. Ed. Maintenance Building, 7801 Lawndale, Chicago

5) 170311003-Taft High School, 6545 W. Hurlbut Street, Chicago

6) 170311601-Cook County trailer, 729 Houston Street, Lemont

7) 170313103-IEPA trailer, 4743 Mannheim Road, Schiller Park

8) 170314002-Cook County trailer, 1820 South 51st Ave., Cicero

9) 170314007-Regional Office Building, 9511 W. Harrison Street, Des Plaines

10) 170314201-Northbrook Water Plant, 750 Dundee Road, Northbrook

11) 170317002-Water Pumping Station, 531 E. Lincoln, Evanston

The SASA monitors of Little Village are located near the main streets such as S Spaulding Ave and W 25 St, Chicago. This makes the $\mathrm{NO}_{2}$ concentrations higher due to the emissions from transportation. In Little Village, the data involved 525 hours to monitor $\mathrm{NO}_{2}$ concentration of Little Village by low-cost sensor "SASA_AQ1" from 4/18/2017 16:00 to 6/28/2017 10:00. EPA Regulatory monitor close to Little Village is site " 17314002 ", which collected 1674 discontinuous hours of $\mathrm{NO}_{2}$ concentration from 4/18/2017 16:00 to 6/28/2017 10:00 [14].

The SASA sensors in South Loop are close to 1530 S State St., Chicago. South Loop is an education zone because there are many schools like Daystar Academy, Perspectives Charter Schools, South Loop Piano Lessons, and Forward Momentum. Thus, the transportation activities will be influenced by the students' traffic behavior and school hours. There will be more regular variations of $\mathrm{NO}_{2}$ concentrations due to emissions from transportation. Additionally, there are also some shops. They also can bring much traffic to the area. Moreover, the monitoring sensors are close to the Perspectives Charter schools and other schools, so the data collected on $\mathrm{NO}_{2}$ concentrations has time variations, as they are influenced by school hours. SASA project involved discontinuous 390 hours to monitor $\mathrm{NO}_{2}$ concentration of South Loop by sensor "SASA_AQ1" from 9/13/2017 13:00 to 10/2/2017 17:00. Regulatory monitor close to South Loop is site "17310063", which collect discontinuous 460 hours of $\mathrm{NO}_{2}$ concentration from 9/13/2017 13:00 to 10/2/2017 17:00 [14].

All of the communities involved in the project are impacted by diesel exhaust. Air quality is impacted by stationary point sources such as coal fired power plants, industrial smoke stacks and mobile sources such as vehicles [15]. Little Village is a Latino neighborhood, which is heavily impacted by industrial activity. South Loop, the non-environmental justice community, is a gentrified neighborhood bordering transportation areas. The area has heavy construction activities and considerable vehicle emissions during rush hours [14]. The monitors involved are as close to the main roads as possible but far away from the heavy industries for focusing the discussion on the influence of transportation emission of $\mathrm{NO}_{x}$

\section{Results}

According to the statistics of Table 2, the mean of 1-hr average $\mathrm{NO}_{2}$ concentration in Little Village in summer is 0.0294 . It is lower than the regulatory level of 
Table 2. Summary statistics of daily averages from Aeroqual sensors deployed in Little Village in the summer (6/7/17-8/10/17) time period.

\begin{tabular}{cccccccc}
\hline \multirow{2}{*}{ Pollutant } & \multirow{2}{*}{ N Hours } & \multirow{2}{*}{$\begin{array}{c}\text { N Days } \\
\text { (Complete) }\end{array}$} & \multicolumn{4}{c}{ Summary Statistics Using Complete Daily Averages (ppm) } \\
\cline { 4 - 8 } & & & Mean & Minimum & Median & Maximum & St. Dev. \\
\hline 1-hr NO & 509 & 19 & 0.0294 & 0.0168 & 0.0301 & 0.0456 & 0.0078 \\
$1-\mathrm{hr} \mathrm{O}_{3}$ & 576 & 24 & 0.0309 & 0.0193 & 0.0318 & 0.0403 & 0.0062 \\
\hline
\end{tabular}

1-hr average $\mathrm{NO}_{2}$ concentration in NAAQS $(0.1 \mathrm{ppm})$, and also lower than the regulatory level of annual average $\mathrm{NO}_{2}$ concentration in NAAQS $(0.053 \mathrm{ppm})$. The data of $\mathrm{NO}_{2}$ contains results for 509 hours, and the data of $\mathrm{O}_{3}$ contains results from 576 hours. Although there are some differences in some days, the time is enough to obtain reasonable estimates of the values for this period of time. Medians are very close to means in Table 2, but they are slightly larger.

In Table 3, the regulatory monitors by EPA have more hours of data than the SASA sensors. The data from sites "17310063" and "17314002" have more than 1500 hourly observations. In a purely statistical sense, estimates of averages and medians are more precise. The mean values of EPA monitors in Table 3 are smaller than the mean values of SASA sensors for $\mathrm{NO}_{2}$ which is to be expected because the SASA data are from closer to the road.

For example, the mean and maximum of the site "17310063" in Table 3 are lower than the data from the SASA monitor in SL as shown in Table 3 collected in the same period. Similarly, the mean and maximum of The EPA monitor "17314002" are lower than the values from the SASA monitor in LV as shown in Table 3. The nitrogen oxide emissions from vehicles are the cause of the larger $\mathrm{NO}_{2}$ concentrations close to streets and roads [4] [6] [13] [15] [22].

Figure 1 shows how the concentrations varied by day at the LV community and at nearby regulatory site. The figure shows the 24-hr average values for the sensor SASA_AQ1_LV, and the 24-hr average value at the regulatory monitor in the area.

Figure 2 shows how the concentrations varied by day at the SL community, and at nearby regulatory sites. The figure shows the 24-hr average values for the sensor SASA_AQ1_SL, and the 24-hr average value at the regulatory monitor in the area.

Figure 1 and Figure 2 show that the values from the SASA data are higher than those from EPA data for daily average $\mathrm{NO}_{2}$ concentration.

Overall, the data of SASA sensors and EPA monitors are very close over the same periods for $\mathrm{NO}_{2}$, though some data shows the SASA collecting values are larger. The monitors by the SASA project are closer to main roads/streets. Erickson et al. state that there will be variations in air quality that depend on how close vehicle emissions are to the instruments that are making air quality measurements [15]. The data values for $\mathrm{NO}_{2}$ are larger when they are taken near the road because of the emission from transportation, and this may explain why some of the SASA values are larger. SASA sensors could be used widely because they have economical and portable advantages. 


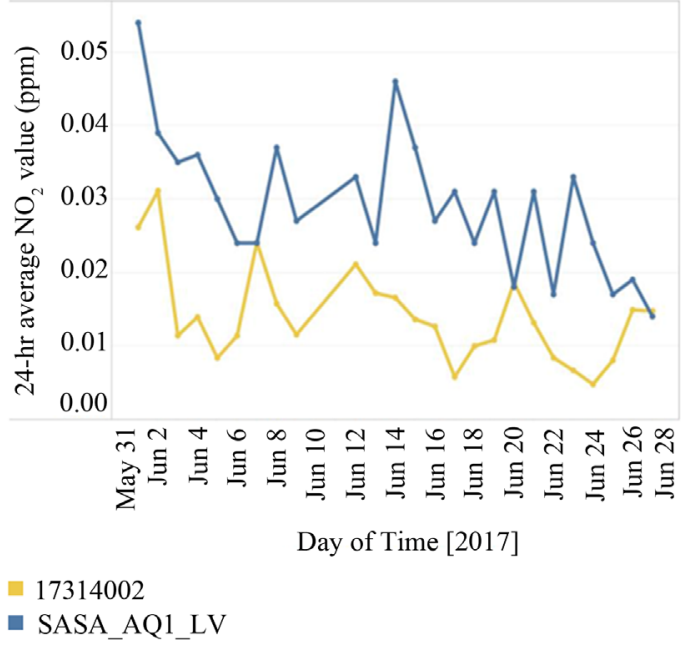

Figure 1. Daily $\mathrm{NO}_{2}$ values for the one sensor deployed in the LV community SASA_AQ1_LV and the nearby regulatory monitor 17314002 .

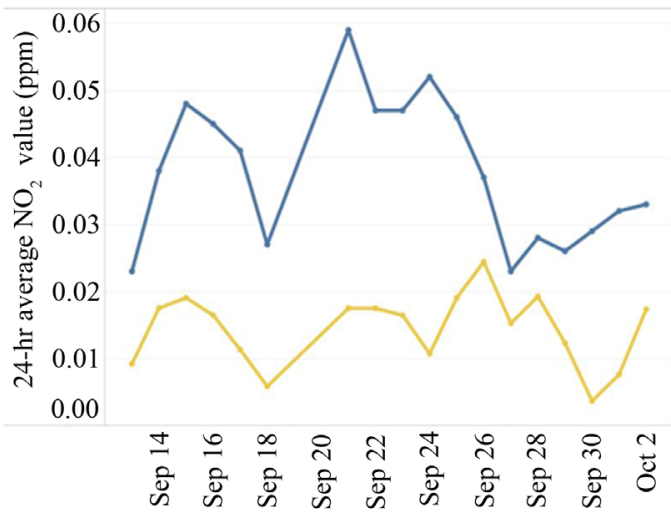

$$
\begin{aligned}
& \text { 17310063 } \\
& \text {-SASA_AQ1_SL }
\end{aligned}
$$

Figure 2. Daily $\mathrm{NO}_{2}$ values for the one sensor deployed in the community SASA_AQ1_SL and the nearby regulatory monitor 17310063 .

Table 3. Summary statistics of daily averages of $1-\mathrm{hr} \mathrm{NO}_{2}$ concentration from SASA

\begin{tabular}{|c|c|c|c|c|c|}
\hline & \multirow{2}{*}{$\begin{array}{c}\text { Number of } \\
\text { Hourly } \\
\text { Values }\end{array}$} & \multicolumn{2}{|c|}{$\begin{array}{c}\text { Summary Statistics Using } \\
\text { Complete Daily Averages (ppm) }\end{array}$} & \multirow[t]{2}{*}{ Start Date } & \multirow[t]{2}{*}{ End Date } \\
\hline & & Mean & Maximum & & \\
\hline $\begin{array}{c}\text { South Loop } \\
\text { (SL) SASA Sensor }\end{array}$ & 390 & 0.038 & 0.086 & $\begin{array}{c}\text { 9/13/2017 } \\
13: 00\end{array}$ & $\begin{array}{c}10 / 2 / 2017 \\
17: 00\end{array}$ \\
\hline $\begin{array}{l}\text { EPA } 17310063 \\
\text { (closest to SL) }\end{array}$ & 460 & 0.015 & 0.049 & $\begin{array}{c}\text { 9/13/2017 } \\
13: 00\end{array}$ & $\begin{array}{c}10 / 2 / 2017 \\
17: 00\end{array}$ \\
\hline $\begin{array}{l}\text { Little Village (LV) } \\
\text { SASA Sensor }\end{array}$ & 525 & 0.029 & 0.097 & $\begin{array}{c}4 / 18 / 2017 \\
16: 00\end{array}$ & $\begin{array}{c}6 / 28 / 2017 \\
10: 00\end{array}$ \\
\hline $\begin{array}{l}\text { EPA } 17314002 \\
\text { (closest to LV) }\end{array}$ & 1674 & 0.014 & 0.062 & $\begin{array}{c}4 / 18 / 2017 \\
16: 00\end{array}$ & $\begin{array}{c}6 / 28 / 2017 \\
10: 00\end{array}$ \\
\hline
\end{tabular}
sensors and EPA monitors deployed in LV and SL [14]. 
Ozone concentrations from SASA sensors were similar to those at nearby regulatory monitors shown in Table 4, but they still have some differences. The EPA monitors "17314201" and "17314002" were used to collect data of $\mathrm{O}_{3}$ concentration from nearby fixed site of Little Village. The site "17314201" is at 750 Dundee Rd, in Northbrook, approximately 20 miles north of the Little Village Environmental Justice organization [16]. Compared with data from Table 2, the mean, median, and maximum of EPA monitor "17314201" are larger than values from the SASA sensor in Little Village in same period. Besides, the minimum of the EPA monitor is lower than the minimum of the SASA sensor, and the standard deviation of the EPA monitor is larger than that of the SASA sensor.

Figure 3 shows how the ozone concentrations varied by hour of the day. The figure shows the 1-hr average values by hour for the sensor, plus the 1-hr average values at the closest regulatory monitors. The 1-hr average value is typically most representative of the diurnal pattern at a given location; the average value is less affected by maximum and minimum. The diurnal patterns are similar between the sensor (SASA_AQ2_LV) and regulatory monitors (17314002 and 17314201). Concentrations are typical of urban sites, and do not indicate higher ozone in the communities than at the regulatory sites.

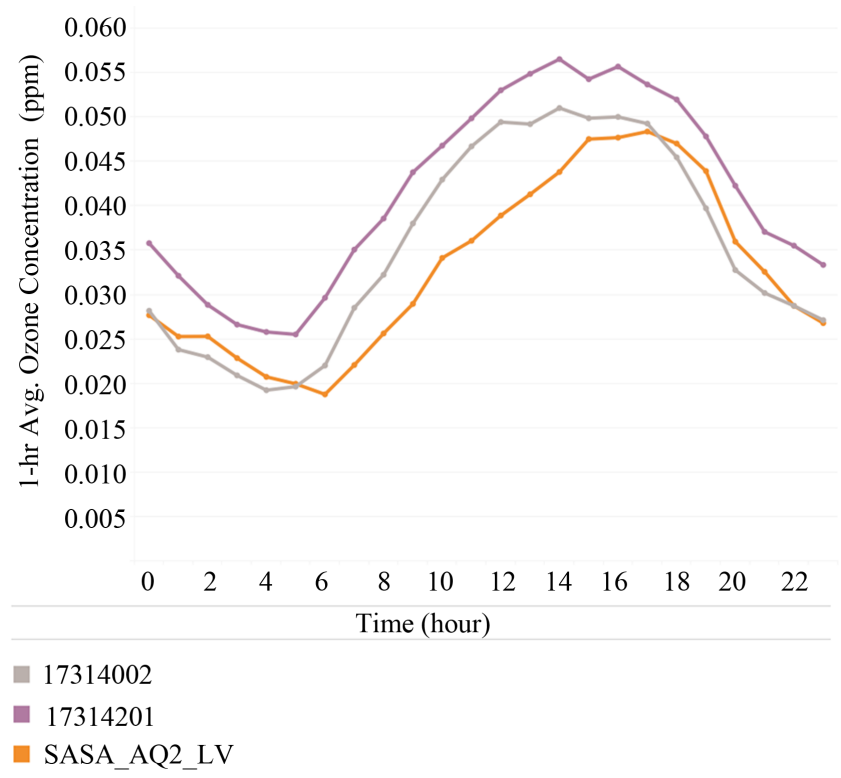

Figure 3. Hourly ozone values for the one sensor deployed in the community and the nearby regulatory monitors 17314002 and 17314201 .

Table 4. Summary statistics of daily averages for 1-hr $\mathrm{O}_{3}$ pollutants measured at the regulatory monitors from nearby fixed site air monitoring locations [14].

\begin{tabular}{cccccccc}
\hline \multirow{2}{*}{$\begin{array}{c}\text { Monitor } \\
\text { Code }\end{array}$} & N & \multirow{2}{*}{$\begin{array}{c}\text { N Days } \\
\text { Hours }\end{array}$} & \multicolumn{4}{c}{ Summary Statistics Using Complete Daily Averages (ppm) } \\
\cline { 5 - 8 } & & Complete) & Mean & Minimum & Median & Maximum & St. Dev. \\
\hline 17314002 & 1260 & 51 & 0.0337 & 0.0187 & 0.0350 & 0.0525 & 0.0080 \\
17314201 & 1522 & 64 & 0.0351 & 0.0188 & 0.0352 & 0.0584 & 0.0094 \\
\hline
\end{tabular}




\section{Discussion of Ozone Formation}

Photochemical smog is a mixture of ozone, nitrogen oxides, and volatile organic compounds (VOCs) that react with sunlight to form mist [17]. Nitrogen dioxide $\left(\mathrm{NO}_{2}\right)$ can be broken down by sunlight to form nitric oxide (NO) and an oxygen radical $(\mathrm{O})$ in Equation (2). There are no serious anthropogenic ozone emissions. Oxygen radicals can then react with atmospheric oxygen $\left(\mathrm{O}_{2}\right)$ to form ozone $\left(\mathrm{O}_{3}\right)$ in Equation (3). Ozone is consumed by nitric oxide to produce nitrogen dioxide and oxygen in Equation (4). The main source of hydrocarbons is the VOCs. Similarly, oxygenated organic and inorganic compounds $\left(\mathrm{RO}_{x}\right)$ react with nitric oxide to produce more nitrogen oxides in Equation (6). Ozone is normally consumed by nitric oxide, as in Equation (4). In daytime, the sufficient sunlight makes more $\mathrm{O}$ as shown in Equation (2). $\mathrm{O}$ reacts with $\mathrm{O}_{2}$ to produce $\mathrm{O}_{3}$ shown in Equation (3), so the increasing $\mathrm{O}_{3}$ might happen in the late morning and afternoon. In Equation (4), $\mathrm{NO}$ will be depleted and more $\mathrm{NO}_{2}$ is produced. Because the mixing ratio of $\mathrm{NO}$ is much lower than $\mathrm{O}_{3}$, Equation (4) does not deplete ozone during the day in background tropospheric air. However, in urban air, Equation (4) can deplete local ozone at night because NO is produced at night and NO mixing ratios at night may exceed those of $\mathrm{O}_{3}(\mathrm{~g})$ [19]. At the same time, if VOCs are present, nitric oxide and nitrogen dioxide can be consumed as in Equations (5) and (6), allowing the buildup of ground level ozone in Equations (3) [18].

$$
\begin{gathered}
2 \mathrm{NO}+\mathrm{O}_{2} \rightarrow 2 \mathrm{NO}_{2} \\
\mathrm{NO}_{2}+\text { sunlight } \rightarrow \mathrm{NO}+\mathrm{O} \\
\mathrm{O}+\mathrm{O}_{2} \rightarrow \mathrm{O}_{3} \\
\mathrm{O}_{3}+\mathrm{NO} \rightarrow \mathrm{NO}_{2}+\mathrm{O}_{2} \\
\mathrm{NO}_{2}+\mathrm{R} \rightarrow \text { products such as PAN } \\
\mathrm{NO}+\mathrm{RO}_{x} \rightarrow \mathrm{NO}_{2}+\text { other products }
\end{gathered}
$$

$\mathrm{O}_{3}$ also can be removed by producing more $\mathrm{OH}$ in Equation (7) \& (8). Therefore, $\mathrm{NO}_{2}$ and $\mathrm{O}_{3}$ concentrations will decrease in daytime due to Equation (7)-(9).

$$
\begin{aligned}
& \mathrm{O}_{3}+h v \rightarrow \mathrm{O}_{2}+\mathrm{O}\left({ }^{1} \mathrm{D}\right) \\
& \mathrm{O}\left({ }^{1} \mathrm{D}\right)+\mathrm{H}_{2} \mathrm{O} \rightarrow 2 \mathrm{OH}
\end{aligned}
$$

More $\mathrm{O}_{3}$ is formed by Equations (1)-(3) by more $\mathrm{NO}_{2}$ in daytime. In nighttime, a lot of ozone production shuts down because of lacking $\mathrm{O}$ and light. At the same time, $\mathrm{NO}_{2}$ could react with ozone in Equation (9) to consume ozone and reduce ozone concentration.

$$
\mathrm{NO}_{2}+\mathrm{O}_{3} \rightarrow \mathrm{NO}_{3}+\mathrm{O}_{2}
$$




\section{Diurnal Variation of $\mathrm{NO}_{2}$ and $\mathrm{O}_{3}$ Concentration}

The daily cycle of $\mathrm{NO}_{2}$ concentration reaches the maximum in the late morning and has smaller nighttime concentrations. The daily cycle of ozone concentration reaches the maximum in the afternoon and also becomes smaller for nighttime concentrations. The observed average diurnal variation of $\mathrm{NO}_{2}$ and $\mathrm{O}_{3}$ concentration during the period are shown in Figure 4 and Figure 5. The ozone concentration slowly increases after the beginning of sun shining in a day, getting to the higher concentration during the daytime, after which it starts to decrease slowly until the next morning. The $\mathrm{NO}_{2}$ concentration also becomes higher during the daytime than during the nighttime, but it usually increases more rapidly than the ozone concentration after the early morning and reaches its peak earlier.

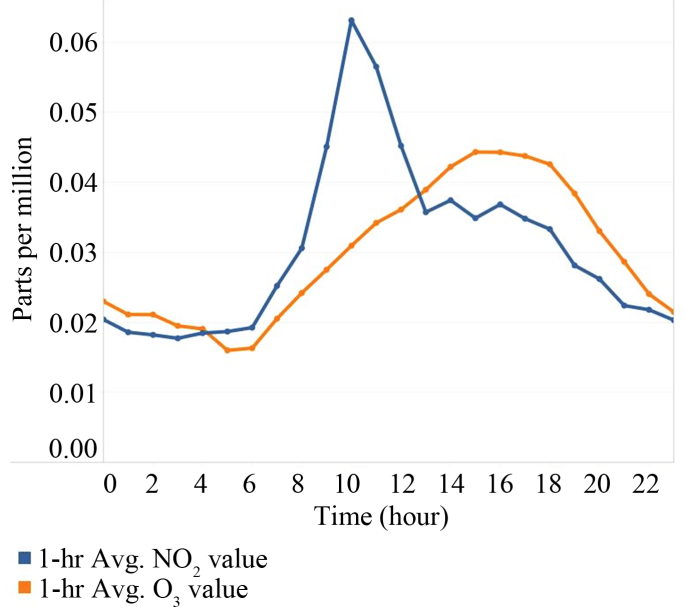

Figure 4. Average of measured values for a daily period of 1-hr average $\mathrm{NO}_{2}$ and $\mathrm{O}_{3}$ concentrations for the LV community. The period is from 16:00 June 2, 2017 to 20:00 June $27,2017$.

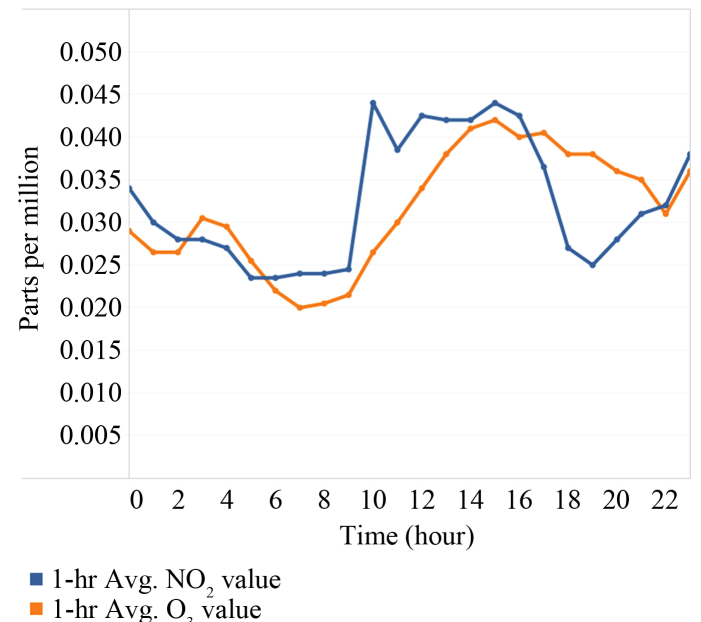

Figure 5. Average of measured values for a daily period of 1-hr average $\mathrm{NO}_{2}$ and $\mathrm{O}_{3}$ concentrations for the SL community. The period is from 0:00 October 1, 2017 to 17:00 October 2, 2017. 
Figure 4 shows values of 1-hr average of $\mathrm{NO}_{2}$ and $\mathrm{O}_{3}$ for a time period in June where the measured values for several days are averaged for each time of day. For the LV community, the minimum of $\mathrm{O}_{3}$ is at about 5:00. After the sun comes up, the ozone concentration increases until reaching the peak value at 15:00. At the same time, $\mathrm{NO}_{2}$ concentration also increases after the sun comes up. The $\mathrm{NO}_{2}$ concentration and $\mathrm{O}_{3}$ concentration both are lower in the nighttime than in the daytime. The change of $\mathrm{O}_{3}$ concentration is influenced by $\mathrm{NO}$ and $\mathrm{NO}_{2}$.

Figure 5 shows values of 1-hr average of $\mathrm{NO}_{2}$ and $\mathrm{O}_{3}$ for a time period in October where the measured values for several days are averaged for each time of day. The maximum average ozone concentration of the SL community is at around 15:00. The minimum average ozone concentration is at about 7:00. From 7:00 to 15:00, the ozone concentrations substantially increase during the daytime. From 15:00 to 6:00 the next day, ozone concentrations dramatically decrease at night. According to the discussion on ozone formation, in daytime, with sufficient sunlight and more $\mathrm{NO}_{2}$ makes more $\mathrm{O}$ as shown in Equation (2). More $\mathrm{O}$ reacts with $\mathrm{O}_{2}$ to produce more $\mathrm{O}_{3}$ as shown in Equation (3). Ozone concentration increases in daytime when $\mathrm{NO}_{x}$, VOCs and solar radiation are present. Sunlight is needed to produce ozone. Thus, the increasing $\mathrm{O}_{3}$ might happen in the daytime with $\mathrm{NO}_{2}$ increasing. It is worth mentioning that transportation is the main reason for higher $\mathrm{NO}_{2}$ concentration during the daytime than at nighttime. More traffic exists during the daytime. The other sources of $\mathrm{NO}_{2}$ emissions come mainly from some industrial plants, which usually run in the daytime, but may run continuously.

In Figure 4, there is the highest $\mathrm{NO}_{2}$ concentration around 10:00, but the highest $\mathrm{O}_{3}$ value is at 15:00. The ozone peak is about 5 hours after the $\mathrm{NO}_{2}$ peak. Although the formation of ozone is deeply influenced by $\mathrm{NO}_{2}$, the tendency of change between $\mathrm{NO}_{2}$ and $\mathrm{O}_{3}$ is not the same. An obvious time lag exists. The period for high values is different because the reactions (shown in Equations (2) \& (3)) need time to happen in the LV community. With the increasing $\mathrm{O}_{3}$ concentration in the afternoon, $\mathrm{NO}_{2}$ concentration is decreasing because $\mathrm{NO}_{2}$ takes part in the reactions to form $\mathrm{O}_{3}$.

In Figure 5, the maximum ozone concentration appears at about 15:00. The diurnal cycle of $\mathrm{NO}_{2}$ is shaped like multiple waves. The peaks exist in the late morning, at noon and in the afternoon.

The SL community has similar tendency of the 24-hr variation of $\mathrm{NO}_{2}$ and $\mathrm{O}_{3}$ concentration to LV. The obvious time lag also exists in Figure 5. The area of high $\mathrm{NO}_{2}$ concentration is during 10:00 to 16:00, but the area of high $\mathrm{O}_{3}$ concentration is during 14:00 to $18: 00$. The $\mathrm{NO}_{2}$ decrease correlates with an increase in $\mathrm{O}_{3}$ from 10:00 to 14:00; it indicates that there is an inverse relationship between $\mathrm{NO}_{2}$ and $\mathrm{O}_{3}$ at some times of the day.

Figure 6 and Figure 7 show the comparison between the average concentrations of $\mathrm{NO}_{2}$ and $\mathrm{O}_{3}$, measured every hour from 16:00 June 2, 2017 to 20:00 June 27, 2017. We have compared two different periods for Little Village. 


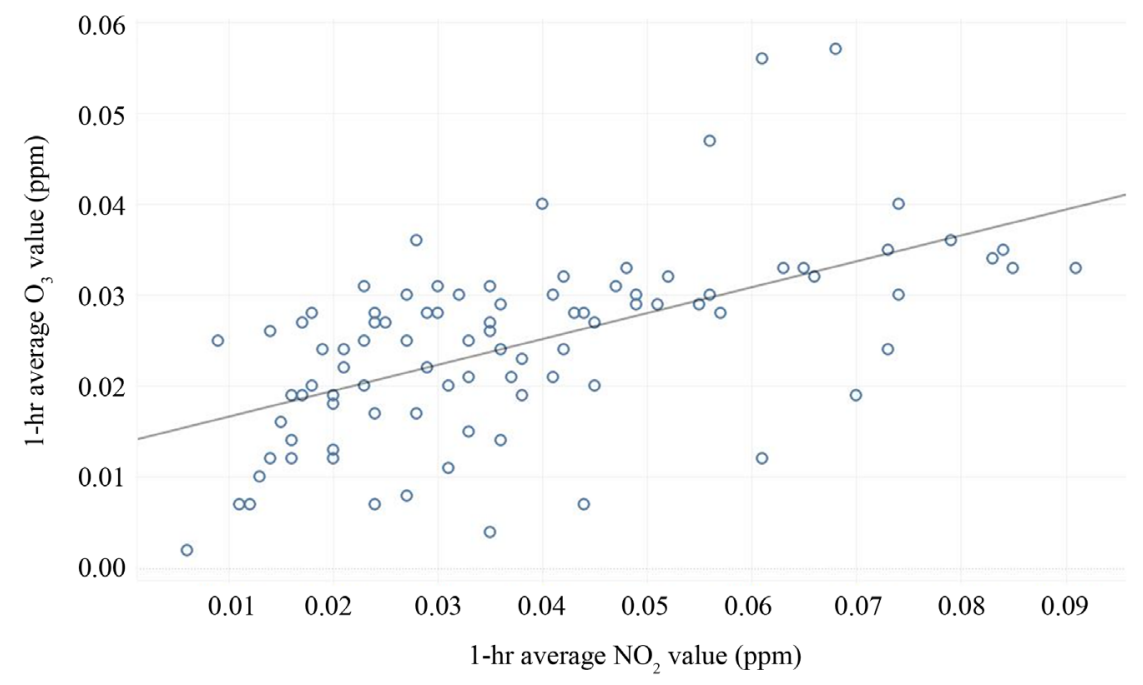

Figure 6. Variation of 1-hr average values of $\mathrm{O}_{3}$ with $\mathrm{NO}_{2}$ from 6:00 to 10:00 in Little Village.

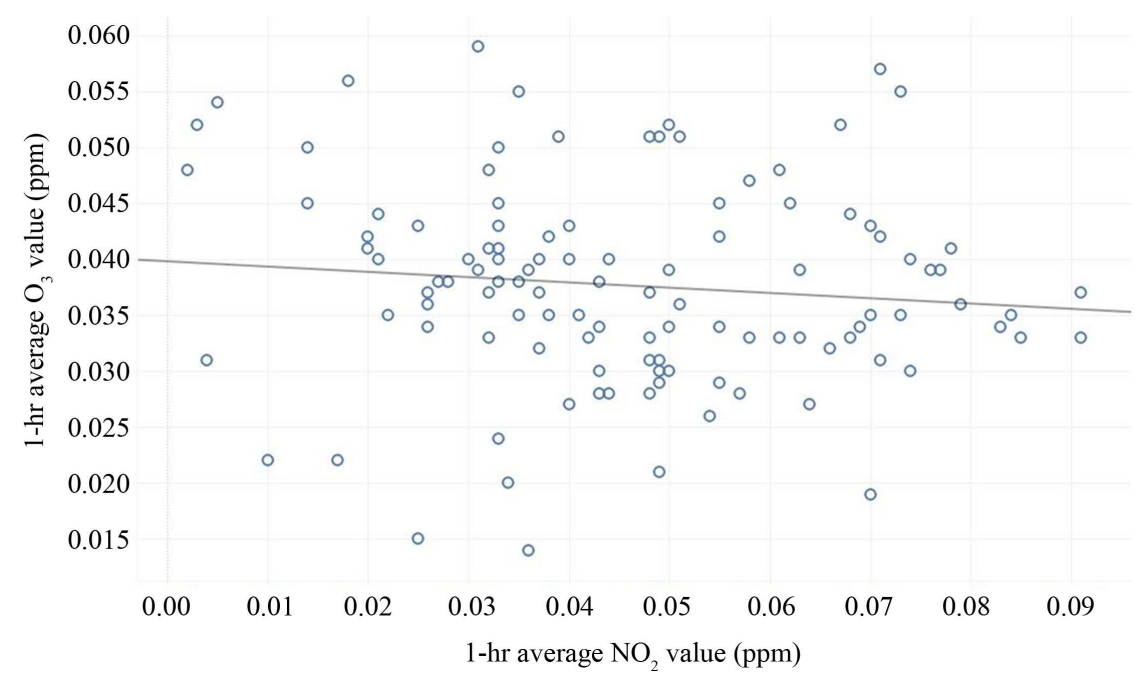

Figure 7. Variation of 1-hr average values of $\mathrm{O}_{3}$ with $\mathrm{NO}_{2}$ from 10:00 to 15:00 in Little Village.

Figure 6 shows the period from 6:00 to 10:00. Figure 7 shows the period from 10:00 to 15:00. They individually present the variation in daytime $\mathrm{O}_{3}$ concentration as a function of $\mathrm{NO}_{2}$. According to Figure $4, \mathrm{O}_{3}$ concentration increases with rapid $\mathrm{NO}_{2}$ increasing from 6:00 to 10:00. $\mathrm{NO}_{2}$ concentration decreases with $\mathrm{O}_{3}$ increasing from 10:00 to 15:00. We fitted the data to linear functions. In Figure 6 the observed data values for the diurnal period are exhibited and the respective relations obtained are: $\mathrm{Y}=0.284$ $\mathrm{X}+0.0138, \mathrm{R}^{2}=0.329$. In Figure 7 the observed data values for the diurnal period are exhibited and the respective relations obtained are: $\mathrm{Y}=-0.0472{ }^{\star} \mathrm{X}+0.0398, \mathrm{R}^{2}=0.264$. These results lead to the conclusions we mentioned: during the early morning (6:00-10:00), $\mathrm{O}_{3}$ and $\mathrm{NO}_{2}$ have a positive correlation, while for the noon and afternoon (10:00-15:00) the correlation between concentrations of $\mathrm{O}_{3}$ and $\mathrm{NO}_{2}$ is inverse. According to the statis- 
tical analysis parameters for the $\mathrm{O}_{3}-\mathrm{NO}_{2}$ relationship listed in Figure 6, the relationship of $\mathrm{O}_{3}$ with $\mathrm{NO}_{2}$ was statistically significant ( $p$ value $<0.0001$, which was $<0.05$ ) from 6:00 to 10:00 in LV, indicating that $\mathrm{O}_{3}$ was sensitive to $\mathrm{NO}_{2}$.

\section{Weekday/Weekends Comparision}

Figure 8 shows that the lowest average $\mathrm{NO}_{2}$ concentrations are on Wednesdays. Thursdays, Fridays, Saturdays, and Sundays have higher $\mathrm{NO}_{2}$ concentrations than Mondays, Tuesdays, and Wednesdays. The data in Figures 8-10 contain average $\mathrm{NO}_{2}$ concentrations and $\mathrm{O}_{3}$ concentrations in each day at Little Village from 16:00 June 2, 2017 to 20:00 June 27, 2017. The Little Village community has many leisure facilities such as restaurants, shopping centers, and other stores. In people's leisure time, the traffic intensity will be greater. Thus, more traffic means more $\mathrm{NO}_{2}$ emissions from vehicle exhaust. The $\mathrm{NO}_{2}$ concentration on the weekends, Thursdays, and Fridays should be higher.

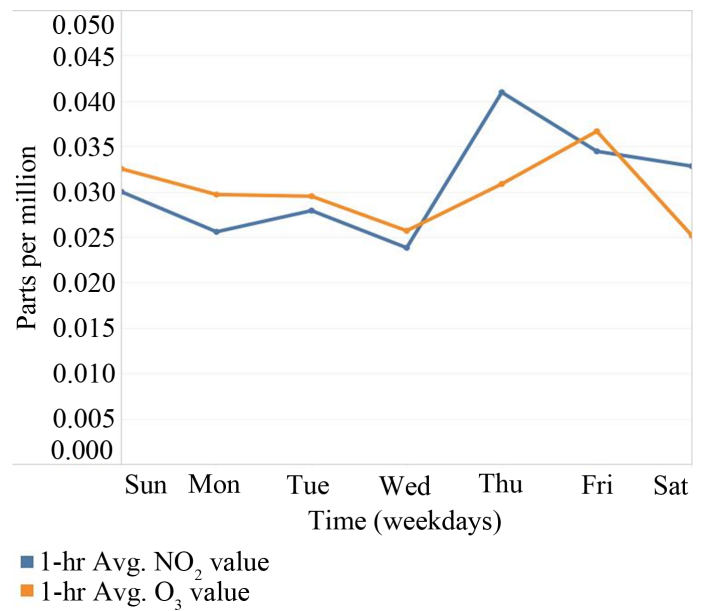

Figure 8. Weekday variation of 24 -hr average $\mathrm{NO}_{2}$ concentrations in $\mathrm{LV}$. The period is from 16:00 June 2, 2017 to 20:00 June 27, 2017.

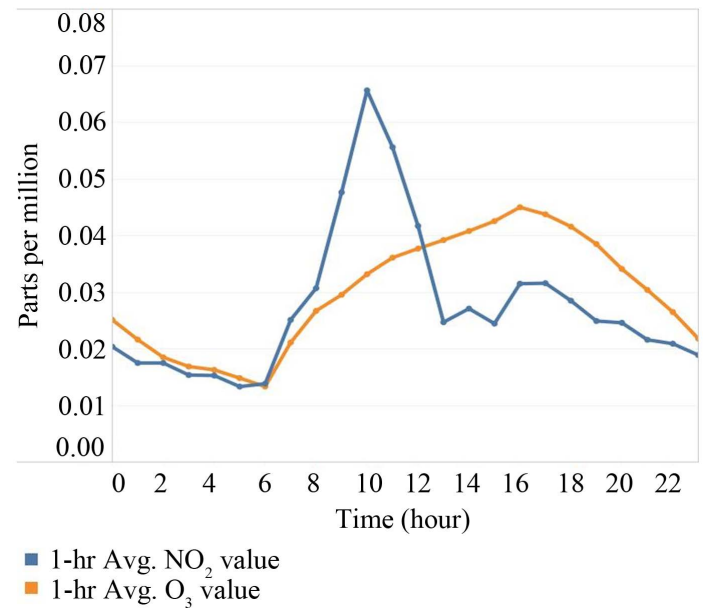

Figure 9. Daily variation of 1-hr average values of $\mathrm{NO}_{2}$ and $\mathrm{O}_{3}$ for workdays in little village. The period is from 16:00 June 2, 2017 to 20:00 June 27, 2017. 


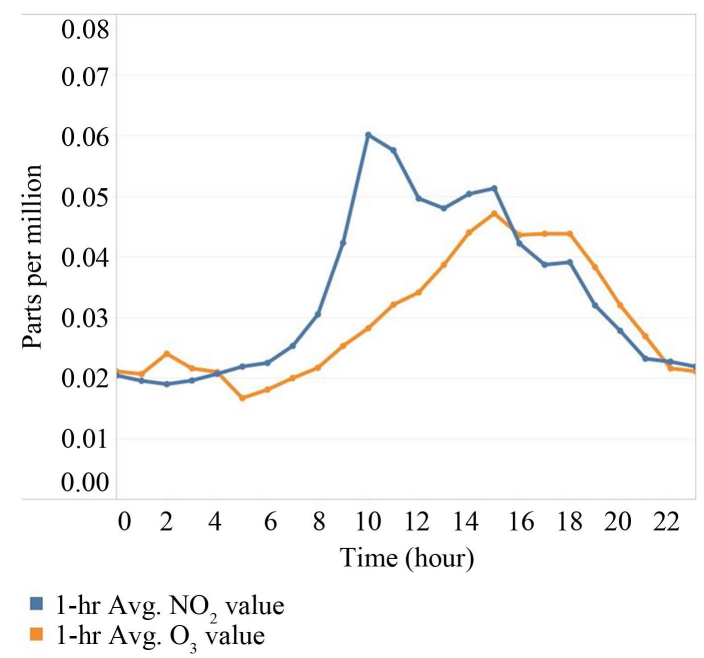

Figure 10. Daily variation of 1-hr average values of $\mathrm{NO}_{2}$ and $\mathrm{O}_{3}$ for weekends in little village. The period is from 16:00 June 2, 2017 to 20:00 June 27, 2017.

In Figure 8, the higher $\mathrm{O}_{3}$ concentrations are on Fridays and Sundays. Han et al. have reported that the average maximum value of $\mathrm{O}_{3}$ on weekends was higher than on workdays [20]. Marr and Harley suggest there is a decrease in absorption of sunlight due to lower fine particle concentration during weekends, resulting in enhanced ozone formation [21].

Figure 9 and Figure 10 show the details of the hourly variations on workdays and weekends in LV during June of 2017. Workdays include Monday, Tuesday, Wednesday, Thursday, and Friday. Weekends include Saturday and Sunday.

The $\mathrm{NO}_{2}$ concentration varies with traffic intensity. Erickson et al. also stated that since traffic density varies with location and time of day, there will be variations in air quality [15]. Figure 9 shows the $\mathrm{NO}_{2}$ concentrations increase starting at $6 \mathrm{am}$. The maximum is at $10 \mathrm{am}$. At night, the concentrations are lower because most of people don't go outside [22]. In Figure 10, on weekends, the concentrations at night are also low but they don't have a consistent moment of peak value. This indicates that people's behavior differs from during the workdays. People like to go outside at any time instead of focusing on hours associated with work. The workdays and weekends differ in terms of the highest value of the 1-hr average $\mathrm{NO}_{2}$ concentrations. On workdays, there are obvious peaks at 10:00. However, on some Saturdays and Sundays, there may be two peaks within a day. There is a possible reason for these two peaks: Dining time produces more traffic [22]. More vehicle emissions on the road cause higher $\mathrm{NO}_{2}$ concentration at more than one time during the day. For example, there is one peak at 10:00 while the other peak is at 15:00 for $\mathrm{NO}_{2}$ values in Figure 10. This is likely caused by traffic flow. Less traffic flow creates fewer $\mathrm{NO}_{2}$ emissions; thus, there is a period of lower concentration between the peaks [22].

Also, the ozone concentration curve for weekends in Figure 10 shows more peaks than the ozone concentration curve for workdays in Figure 9. At the same time, the $\mathrm{NO}_{2}$ concentration curve for weekends in Figure 10 also has more 
peaks than the $\mathrm{NO}_{2}$ concentration for workdays in Figure 9. The results of comparison indicate ozone concentration on weekends is due to the influence of $\mathrm{NO}_{2}$.

\section{Monthly Variation}

Higher concentrations of nitrogen dioxide were measured at all measuring points in the urban setting during the winter than during the summer since the winter weather conditions reduce the self-cleaning capacity of the air in the city and increase the use of energy for heating; fuel consumption by vehicles is also higher. Nitrogen dioxide concentrations greatly exceed the measured value of annual average, during the winter, due to emissions from heating buildings.

In Figure 11, the $\mathrm{NO}_{2}$ concentrations are lower during the summer than in the winter. The site 17314002 has smaller changes in a year. It has a peak in November and valleys during March and July. The site 17310076 has the highest value in December and the lowest value in August. The site 17310063 has the highest value in December and the lowest value in May. In sum, the peak times are during November and December, though the locations show differences in $\mathrm{NO}_{2}$ concentrations. The different sites had the lowest concentrations in March, May, and August. Winters have obviously higher $\mathrm{NO}_{2}$ concentrations than in the summer.

However, the $\mathrm{O}_{3}$ concentrations are higher during the summer than in the winter. The peak times are both during June. The site 17314201 had the lowest concentration in November, and the site 17314002 had the lowest concentration in November and January. Summers have higher $\mathrm{O}_{3}$ concentrations than in the winter.

According to the results of monthly variation, ozone concentrations have inverse relationship with $\mathrm{NO}_{2}$ concentration for monthly change. When the $\mathrm{NO}_{2}$ concentration is higher in winter, the ozone concentration is lower.

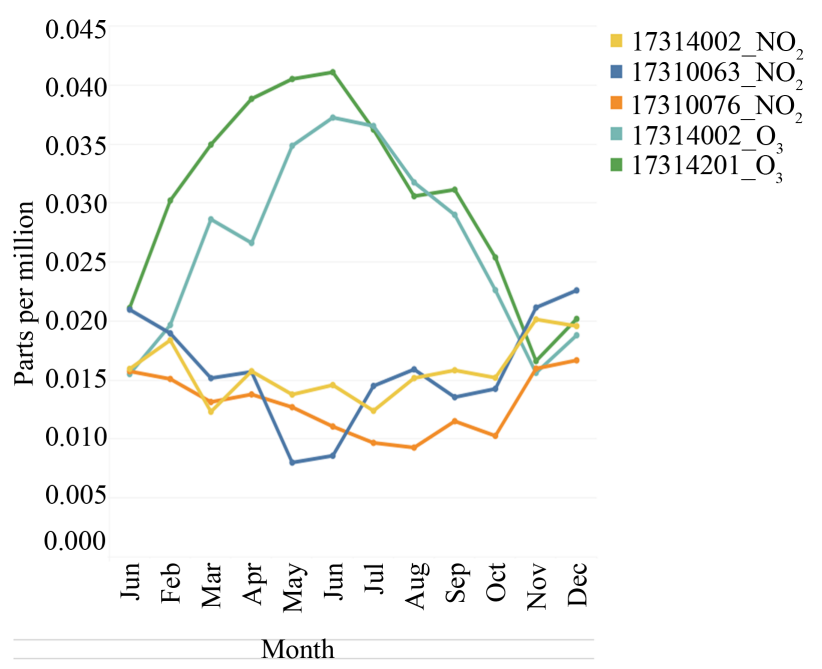

Figure 11. Monthly variation of 24-hr average values of $\mathrm{NO}_{2}$ and $\mathrm{O}_{3}$ for weekends in little village. The period is from January 1, 2017 to December 31, 2017. 


\section{Improving Air Quality}

There is a need to improve air quality in the Chicago metropolitan area because of the significant health benefits associated with better air [3] [4] [6] [16] [23]-[28]. Table 5 shows that there are several counties that are not meeting the NAAQS for ozone [3]. Cook county has a number of sites where ozone concentrations often exceed regulatory values because of large emissions of $\mathrm{NO}_{\mathrm{x}}$ and VOCs; see Table 6 and Table 7. Table 8 and Table 9 provide information on sources of VOCs that contribute to ozone formation.

Table 5. Ozone scores in several counties in the Chicago metropolitan area.

\begin{tabular}{cccc}
\hline County & \multicolumn{3}{c}{ Ozone scores } \\
\cline { 2 - 4 } & $\mathbf{2 0 1 4 - 2 0 1 6}$ & $\mathbf{2 0 1 5 - 2 0 1 7}$ & $\mathbf{2 0 1 6 - 2 0 1 8}$ \\
\hline Cook & 9.8 & 14.0 & 19.2 \\
DuPage & 3.7 & 3.7 & 5.0 \\
Kane & 3.0 & 3.0 & 4.7 \\
Lake & 5.3 & 6.0 & 8.0 \\
McHenry & 3.3 & 3.3 & 5.7 \\
\hline
\end{tabular}

From annual reports of the American Lung Association [3].

Table 6. Emissions of nitrogen oxides $\left(\mathrm{NO}_{\mathrm{x}}\right)$ and volatile organic compounds.

\begin{tabular}{ccc}
\hline \multicolumn{2}{c}{ (VOCs) for counties in the Chicago metropolitan area in tons per year (tpv). } \\
\hline County & Total NO & Total VOCs \\
\hline Cook & 95,864 & 86,253 \\
DuPage & 22,000 & 19,742 \\
Kane & 11,335 & 10,533 \\
Lake & 17,615 & 15,143 \\
McHenry & 6675 & 6353 \\
Will & 23,750 & 14,607 \\
Total & 177,239 & 152,631 \\
\hline
\end{tabular}

Data from 2014 National Emissions Inventory [26].

Table 7. Fourth highest 8-hour ozone concentration in parts per million for monitoring sites in Cook county, IL.

\begin{tabular}{clllll}
\hline Monitoring Site & $\mathbf{2 0 1 4}$ & $\mathbf{2 0 1 5}$ & $\mathbf{2 0 1 6}$ & $\mathbf{2 0 1 7}$ & $\mathbf{2 0 1 8}$ \\
\hline 170310001 & 0.066 & 0.066 & 0.075 & 0.078 & 0.079 \\
170310032 & 0.067 & 0.066 & 0.077 & 0.074 & 0.076 \\
170310076 & 0.067 & 0.065 & 0.075 & 0.078 & 0.074 \\
170311003 & 0.065 & 0.068 & 0.075 & 0.060 & 0.073 \\
170311601 & 0.070 & 0.066 & 0.073 & 0.070 & 0.068 \\
170313103 & 0.063 & 0.058 & 0.067 & 0.061 & 0.065 \\
170314002 & 0.063 & 0.061 & 0.076 & 0.068 & 0.072 \\
170314007 & 0.069 & 0.068 & 0.076 & 0.071 & 0.075 \\
170314201 & 0.068 & 0.068 & 0.079 & 0.070 & 0.083 \\
170317002 & 0.072 & 0.070 & 0.076 & 0.073 & 0.084 \\
\hline
\end{tabular}

Data from Illinois EPA [25] [26]. The locations of these monitors are shown on a map in reference [25]. 
Table 8. Sources of volatile organic compounds (VOCs) and nitrogen oxides $\left(\mathrm{NO}_{\mathrm{x}}\right)$ in ambient air in percent, in the Chicago metropolitan area.

\begin{tabular}{ccc}
\hline Source & VOCs & $\mathrm{NO}_{\mathrm{x}}$ \\
\hline Off-road & 21 & 30 \\
On-road & 24 & 43 \\
Area & 46 & 11 \\
Point & 9 & 16 \\
\hline
\end{tabular}

Data from Illinois environmental protection agency [23].

Table 9. Sources of volatile organic compounds (VOCs) and nitrogen oxides $\left(\mathrm{NO}_{\mathrm{x}}\right)$ in ambient air in percent, in Lake County, IL.

\begin{tabular}{ccc}
\hline Source & VOCs & $\mathrm{NO}_{\mathrm{x}}$ \\
\hline Mobile & 49.9 & 70.1 \\
Solvents & 22.1 & 0.1 \\
Fuel Combustion & 2.0 & 28.3 \\
Industrial processes & 0.9 & 0.8 \\
Fires & 1.5 & 0.1 \\
Miscellaneous & 23.6 & 0.6 \\
\hline
\end{tabular}

Data from U.S. EPA [24].

The ozone pollution problems can be addressed by reducing nitrogen oxide emissions and releases of VOCs [4] [6]. One action to take is to reduce combustion emissions in the Chicago metropolitan area. There is already interest and action to replace diesel powered buses with electric buses. The Chicago Transit Authority has already reported that operating costs and maintenance costs are less for their electric buses [27]. When health and quality of life are considered, electric buses are the best choice when it is time to purchase a new bus. The plan is to have all electric buses by 2040 [28].

The transition to electric power for school buses has started, and many school districts have demonstrated interest in participating in the transition to electric school buses. Since school buses are needed in mornings and afternoons, there is time for charging during the day and at night, and battery capital costs are less than for transit buses because of the shorter range that is needed.

The electrification of transportation reduces both $\mathrm{NO}_{\mathrm{x}}$ and VOCs [23]. The transition to electric passenger cars has made great progress [6]. Electric vehicles are being used for taxis in many locations [6]. Since EVs are less expensive to operate and maintain, there is significant interest in using EVs in metropolitan areas for a number of applications including delivery vehicles, police cars, and service vehicles [6].

In China, there has been a major transition to electric bicycles for transportation to work, shopping, and other destinations [6]. There are often significant benefits in communities where improvements are made for biking and walking. 
Since wind and solar energy are now the low cost options to add electric generating capacity, the portion of electricity being generated without combustion emissions continues to increase. Electric vehicle charging can take place whenever the vehicle is parked, and there are benefits in doing it when the grid has power that needs to be delivered.

One of the sources of VOC emissions is from consumer products. These emissions can be addressed through public education on how to reduce them. There are benefits in helping the public understand ozone pollution, the process of ozone formation, and what can be done to reduce emissions.

There are many beneficial policy choices that will help improve air quality. Some examples include incentives to purchase and use electric vehicles, a tax on carbon emissions, and a permit requirement to operate an internal combustion vehicle in the congested part of the city.

\section{Conclusion}

This article analyzes the concentrations of $\mathrm{NO}_{2}$ and $\mathrm{O}_{3}$ collected in Chicago in 2017. The daily cycle of $\mathrm{NO}_{2}$ concentration reaches the maximum in the late morning and has smaller nighttime concentrations, and the daily cycle of ozone concentration reaches the maximum in the afternoon and also becomes smaller for nighttime concentrations. After the sun rises, the ozone concentration rises slowly, and reaches a peak in the afternoon, and then drops until the next morning. Ozone formation involves photochemical reactions that are impacted by solar radiation and temperature. The diurnal ozone change is influenced by $\mathrm{NO}_{2}$, and the $\mathrm{NO}_{2}$ concentration is influenced by transportation emissions. The $\mathrm{NO}_{2}$ is from transportation emissions and other emissions. Both $\mathrm{NO}_{2}$ and VOCs impact the daily cycle of ozone levels. The weekend effects of $\mathrm{NO}_{2}$ concentration on ozone concentration are different because traffic patterns are different. Ozone concentration has an inverse relationship with $\mathrm{NO}_{2}$ concentration for monthly change. Reducing greenhouse gas emissions and improving air quality are significant challenges [23]. The regional background $\mathrm{O}_{3}$ concentration in Chicago is of concern because ozone air quality does not meet environmental protection standards. Ozone pollution can be reduced by transitioning to electric buses, taxis, and other changes that reduce emissions from combustion processes.

\section{Acknowledgements}

The authors thank all who helped with the SA/SA project. Some of the data were collected under Assistance Agreement RD 83618201 awarded by the U.S. Environmental Protection Agency to Kansas State University. The data and this manuscript have not been reviewed by EPA. The views expressed in this manuscript are those of the authors and do not necessarily reflect those of the agency. EPA does not endorse any products or services mentioned in this publication.

\section{Conflicts of Interest}

The authors declare no conflicts of interest regarding the publication of this paper. 


\section{References}

[1] Knowlton, K., Rosenthal, J.E., Hogrefe, C., et al. (2004) Assessing Ozone-Related Health Impacts under a Changing Climate. Environmental Health Perspectives, 112, 1557-1563. https://doi.org/10.1289/ehp.7163

[2] US EPA (2015) Ground-Level Ozone Basics. US EPA. https://www.epa.gov/ground-level-ozone-pollution/ground-level-ozone-basics

[3] American Lung Association (2019) State of the Air 2019. American Lung Association, Chicago. https://www.lung.org/about-us/media/top-stories/state-of-the-air-2019.html

[4] Jing, P., Lu, Z., Xing, J., et al. (2014) Response of the Summertime Ground-Level Ozone Trend in the Chicago Area to Emission Controls and Temperature Changes, 2005-2013. Atmospheric Environment, 99, 630-640. https://doi.org/10.1016/j.atmosenv.2014.10.035

[5] Newmark, G.L. (2001) Emissions Inventory Analysis of Mobile Source Air Pollution in Tel Aviv, Israel. Transportation Research Record, 1750, 40-48. https://doi.org/10.3141/1750-05

[6] Erickson, L. and Brase, G. (2020) Reducing Greenhouse Gas Emissions and Improving Air Quality: Two Interrelated Global Challenges. CRC Press, Boca Raton. https://doi.org/10.1201/9781351116589

[7] Gao, H.O. and Niemeier, D.A. (2008) Using Functional Data Analysis of Diurnal Ozone and $\mathrm{NO}_{x}$ Cycles to Inform Transportation Emissions Control. Transportation Research Part D: Transport and Environment, 13, 221-238. https://doi.org/10.1016/j.trd.2008.02.003

[8] Gray, K.A. and Finster, M.E. (1999) The Urban Heat Island, Photochemical Smog, and Chicago: Local Features of the Problem and Solution. Northwestern University, Evanston.

[9] US EPA (2019) Eight-Hour Average Ozone Concentrations. Ground-Level Ozone. New England. US EPA. Region 1. EPA New England. https://www3.epa.gov/region1/airquality

[10] Holloway, T., Spak, S.N., Barker, D., et al. (2008) Change in Ozone Air Pollution over Chicago Associated with Global Climate Change. Journal of Geophysical Research: Atmospheres, 113, D22306. https://doi.org/10.1029/2007JD009775

[11] Erickson, L.E. and Jennings, M. (2017) Energy, Transportation, Air Quality, Climate Change, Health Nexus: Sustainable Energy Is Good for Our Health. AIMS Public Health, 4, 47-61. https://doi.org/10.3934/publichealth.2017.1.47

[12] Pratt, D., et al. (2020) Gov. J.B. Pritzker Issues Order Requiring Residents to "Stay at Home" Starting Saturday. chicagotribune.com. https://www.chicagotribune.com/coronavirus/ct-coronavirus-illinois-shelter-in-pla ce-lockdown-order-20200320

[13] (n.d.) Shared Air/Shared Action (SA2): Community Empowerment through Low-Cost Air Pollution Monitoring. Center for Hazardous Substance Research. https://engg.ksu.edu/chsr/SA2\%20Air\%20Monitoring\%20Project

[14] STI Report (2018) Little Village summary_rev. STI Report. https://www.dropbox.com/sh/0c9rzr0kjihbl0d/AAADQIgirHYTUJ8S6qtKH1ypa?dl $=0$

[15] Erickson, L.E., Griswold, W., Maghirang, R.G. and Urbaszewski, B.P. (2017) Air Quality, Health and Community Action. Journal of Environmental Protection, 8, 1057. https://doi.org/10.4236/jep.2017.810067 
[16] STI Report (2018) Methods_Appendix. STI Report. https://www.dropbox.com/sh/0c9rzr0kjihbl0d/AAADQIgirHYTUJ8S6qtKH1ypa?dl $=0$

[17] US EPA (2015) EnviroAtlas Fact Sheets. US EPA. https://enviroatlas.epa.gov/enviroatlas/DataFactSheets/pdf/ESC/NitrogenDioxidere movedannuallybytreecover.pdf

[18] US EPA (2004) EPA Information-Photochemical Smog-What It Means for Us. US EPA.

https://studylib.net/doc/8126524/epa-information---photochemical-smog-\%E2\%80 \%94-what-it-means-for-us

[19] Jacobson, Z.M. (2012) Air Pollution and Global Warming. History, Science, and Solutions. Cambridge University Press, Cambridge.

https://doi.org/10.1017/CBO9781139109444

[20] Han, S., Bian, H.Y., Feng, Y., et al. (2011) Analysis of the Relationship between $\mathrm{O}_{3}$, $\mathrm{NO}$ and $\mathrm{NO}_{2}$ in Tianjin, China. https://doi.org/10.4209/aaqr.2010.07.0055

[21] Marr, L.C. and Harley, R.A. (2002) Modeling the Effect of Weekday-Weekend Differences in Motor Vehicle Emissions on Photochemical Air Pollution in Central California. Environmental Science \& Technology, 36, 4099-4106. https://doi.org/10.1021/es020629x

[22] Wang, Z. (2020) Air Quality Analysis of Nitrogen Oxides and Relationships with Ozone Pollution. M.S. Thesis, Kansas State University, Manhattan. https://krex.k-state.edu/dspace/handle/2097/40363

[23] CMAP (n.d.) Air Quality CMAP Regional Snapshot. Chicago Metropolitan Agency for Planning, Chicago.

[24] Beltran, T. (2014) The State of Lake County's Air Quality Report 2014. Health Department and Community Health Center, Lake County. https://www.lakecountyil.gov/148/Health-Department-Community-Health-Cente

[25] Kim, J. (2018) Illinois Air Quality Report 2018. Illinois Environmental Protection Agency, Springfield. http://www.epa.illinois.gov

[26] U.S. EPA (n.d.) Chicago, IL-IN-WI Nonattainment Area: Final Area Designations for the 2015 Ozone National Ambient Air Quality Standards. Technical Support Document (TSD), U.S. EPA. https://www.epa.gov

[27] Chicago Transit Authority (2018) CTA Expands Electric Bus Fleet. Chicago Transit Authority, Chicago. http://transitchicago.com

[28] Wanek-Liibman, M. (2019) Chicago City Council Approves Transition to 100\% Renewable Energy. Mass Transit, Endeavor Business Media, Nashville. http://masstransitmag.com 